\title{
Platelets and cardiac arrhythmia
}

\author{
Jonas S. S. G. de Jong ${ }^{\text {* }}$ and Lukas R. C. Dekker ${ }^{2}$ \\ 1 Department of Cardiology, Academic Medical Center, Amsterdam, Netherlands
}

2 Department of Cardiology, Catharina Hospital, Eindhoven, Netherlands

\section{Edited by:}

Sami Noujaim, University of Michigan,

USA

\section{Reviewed by:}

Sandeep Pandit, University of

Michigan, USA

Ruben Coronel, Academic Medical

Center, Netherlands

*Correspondence:

Jonas S. S. G. de Jong, Department of Cardiology, Academic Medical Center, B2-235, Meibergdreef 9, 1105 AZ,

Amsterdam, Netherlands.

e-mail: jssgdejong@dri.nl
Sudden cardiac death (SCD) remains one of the most prevalent modes of death in industrialized countries, and myocardial ischemia due to thrombotic coronary occlusion is its primary cause. The role of platelets in the occurrence of SCD extends beyond coronary flow impairment by clot formation. Here we review the substances released by platelets during clot formation and their arrhythmic properties. Platelet products are released from three types of platelet granules: dense core granules, alpha-granules, and platelet lysosomes. The physiologic properties of dense granule products are of special interest as a potential source of arrhythmic substances. They are released readily upon activation and contain high concentrations of serotonin, histamine, purines, pyrimidines, and ions such as calcium and magnesium. Potential arrhythmic mechanisms of these substances, e.g., serotonin and high energy phosphates, include induction of coronary constriction, calcium overloading, and induction of delayed after-depolarizations. Alpha-granules produce thromboxanes and other arachidonic-acid products with many potential arrhythmic effects mediated by interference with cardiac sodium, calcium, and potassium channels. Alphagranules also contain hundreds of proteins that could potentially serve as ligands to receptors on cardiomyocytes. Lysosomal products probably do not have an important arrhythmic effect. Platelet products and ischemia can induce coronary permeability, thereby enhancing interaction with surrounding cardiomyocytes. Antiplatelet therapy is known to improve survival after myocardial infarction. Although an important part of this effect results from prevention of coronary clot formation, there is evidence to suggest that antiplatelet therapy also induces anti-arrhythmic effects during ischemia by preventing the release of platelet activation products.

Keywords: platelets, arrhythmias, cardiac, sudden death, ventricular fibrillation

\section{CARDIAC ARRHYTHMIAS}

Sudden cardiac death (SCD) remains one of the most prevalent modes of death in industrialized countries, claiming almost a million deaths annually in Western Europe and the United States (Zipes et al., 2006; Chugh et al., 2008). Ventricular fibrillation (VF) in the setting of coronary artery disease is the most common underlying arrhythmia (Zipes et al., 2006) as acute coronary thrombosis is observed in $74-79 \%$ of SCD victims at autopsy (Davies and Thomas, 1984; Frink et al., 1988).

Arrest of blood flow to the myocytes results in a complex ischemic reaction that includes an increase in outward potassium current (Wilde et al., 1990), a triphasic increase of extracellular potassium (Coronel et al., 1988), a decrease of action potential (AP) duration (Saito et al., 2005), and depolarization of resting membrane potential. Decrease in $\mathrm{pH}$ results in activation of the $\mathrm{Na}^{+}-\mathrm{H}^{+}$exchange pathway extruding $\mathrm{H}^{+}$from the cell. This leads to $\mathrm{Ca}^{2+}$ loading as a consequence of reverse-mode action of the $\mathrm{Na}-\mathrm{Ca}$ exchanger (NXC; Dekker et al., 1996; Akar and Akar, 2007). $\mathrm{Ca}^{2+}$ loading of ischemic cardiomyocytes has several pro-arrhythmic effects: abnormal sarcoplasmic reticulum $\mathrm{Ca}^{2+}$ cycling and promotion of AP alternans, delayed after-depolarizations (DADs), and decreased gap-junction conductance ultimately leading to uncoupling of cell-to-cell connections (Kléber et al., 1987). Furthermore, reactive oxygen species are released, resulting in changes in ion channel function (Carmeliet, 1999) and mitochondrial dysfunction
(Akar and Akar, 2007). These events create a hostile environment that renders the myocardium prone to arrhythmias (Coronel et al., 1991).

Ventricular fibrillation during ischemia results from re-entrant excitation. Onset of re-entry may not only result from injury current (Lown and Wolf, 1971; Verkerk et al., 2000), but may also be evoked by triggered beats originating from early and delayed afterpotentials (EADs and DADs; Ter Keurs and Boyden, 2007).

Platelets play an important role in the occurrence of SCD. Traditionally, the role of platelets in SCD was believed to be limited to their ability to halt coronary flow by clot formation. However, there is an increasing body of evidence suggesting that the process of clot formation has arrhythmic properties beyond the arrest of distal perfusion. Animal experiments have shown that platelet activation increases the susceptibility of ischemic myocardium to VF. Coronel et al. (1997) showed that intracoronary thrombi have profibrillatory effects. In their pig model, the left anterior descending artery (LAD) was ligated, and blood with thrombin-induced platelet activation or heparinized blood injected distally. Notwithstanding a comparable area of ischemia, thrombi injection resulted in VF in 4/7 pigs vs. 2/19 control pigs. Similarly, in a dog model of regional myocardial ischemia, $51 \%$ of control animals developed VF after coronary artery embolization. However, following pre-treatment with carbenicillin, a strong inhibitor of platelet aggregation, or estradiol cypionate, which induces severe thrombocytopenia, the 
incidence of VF was reduced to $9 \%$ and 0 , respectively (Johnson et al., 1981). Platelet activation results in the release of platelet products, the so-called secretome, which includes organic substances [e.g., adenosine-5' -triphosphate (ATP), serotonin, and histamine] and more than 2000 proteins (Coppinger et al., 2004). Many of these substances can alter electrophysiological properties of the heart in various animal species, supporting the notion that activated platelets exert pro-arrhythmic effects (Figure 1; Hoffman et al., 1996, 1997; Flores et al., 1999). Conversely, platelet antagonists counteract ischemia-induced arrhythmias in animal studies (Wainwright et al., 1989; Ahn et al., 1999).

\section{PLATELET ADHESION AND ACTIVATION}

Platelets are small anuclear cells $(2-3 \mu \mathrm{m}, 7.5-1.5 \mathrm{fL})$, which are derived from defragmentation of megakaryocytes. Platelets have a life-span of 8-12 days, and the blood of healthy individuals has a platelet concentration of 150-400 × 10\% /L (Greer, 2008). Coronary plaque rupture results in exposure of subendothelium-containing collagen, collagen-bound-von Willebrand factor (vWf), fibronectin, and laminin. Platelet membranes expose an array of adherence proteins waiting to adhere with these exposed molecules. Upon adhesion, intracellular signal transduction pathways are activated. Granules fuse with the platelet membrane leading to a platelet-shape change, expulsion of granule contents and exposure of formerly intragranular membrane molecules on the outside of the platelet. Amongst these are glycoprotein 1b/V/IX and glycoprotein $\alpha_{\text {IIb }} \beta_{3}$ receptors which mediate platelet aggregation and finally clot formation.

Three types of platelet granules are morphologically distinct (Figure 2; Table 1): dense core granules ( $\delta$-granules), alpha-granules, and platelet lysosomes $(\lambda$-granules; Rendu and BrohardBohn, 2001).

About three to eight dense granules are present per platelet. They are inherently electron dense when viewed in electron microscopy. Dense granules are acidic ( $\mathrm{pH}$ 6.1) and contain platelet agonists
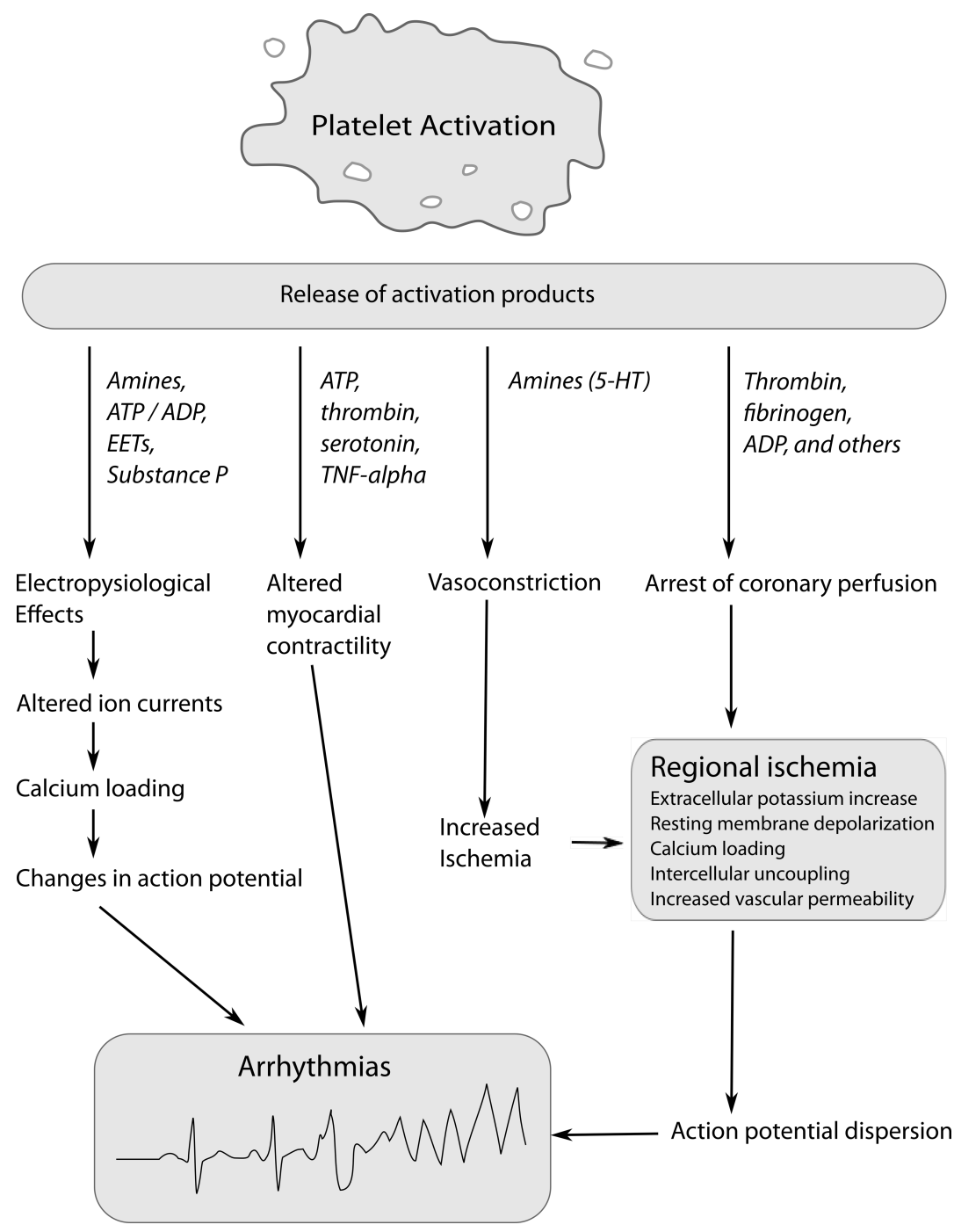

FIGURE 1 | Mechanisms by which platelet activation and release of platelet products could induce arrhythmias during ischemia. ADP/ATP, adenosine diphosphate, adenosine triphosphate; EETs, epoxyeicosatrienoic acids; 5 -HT, 5-hydroxytryptamine (serotonin); TNF- $\alpha$, tumor necrosis factor- $\alpha$. 


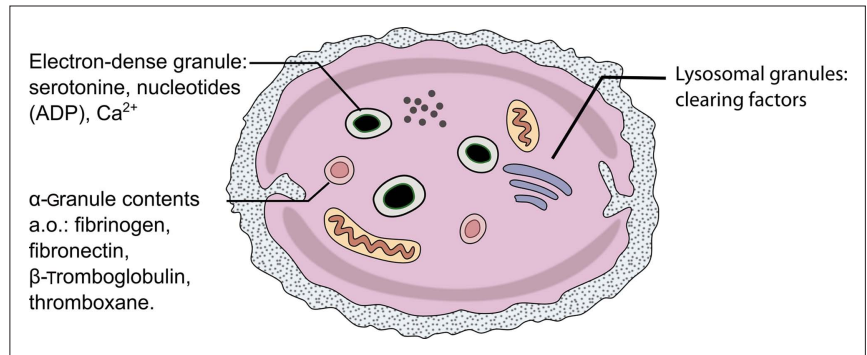

FIGURE 2 | Schematic drawing of a single platelet and its contents.

that serve to amplify platelet activation. They are the most rapidly secreted granules and release, amongst others, adenosine diphosphate (ADP), ATP, guanosine $5^{\prime}$-triphosphate (GTP), guanosine diphosphate (GDP), $\mathrm{Ca}^{2+}$, magnesium pyrophosphate, and amines such as serotonin and histamine. After exocytosis, ADP acts as a platelet agonist and is important in the activation of additional circulating platelets (McNicol and Israels, 1999).

Alpha-granules release various proteins involved in platelet interaction. Proteomic studies of the platelet secretome have yielded a list of more than 2000 of such proteins (Coppinger et al., 2004; McRedmond et al., 2004). These proteins are involved in platelet interactions (glycoprotein $\alpha_{\mathrm{IIb}} \beta_{3}$ receptor, fibrinogen, $\mathrm{vWF}$, thrombospondin-I, fibronectin, vitronectin, GAS6), coagulation and fibrinolysis (plasminogen, plasminogen activator inhibitor-1, protein S), and chemotaxis and cell signaling (transforming growth factor- $\beta$, platelet-derived growth factor; Gresele et al., 2002). Some of the proteins are known as markers of platelet activation (P-selectin, $\beta$-thromboglobulin, platelet factor 4). Alpha-granules also contain plasma proteins such as albumin, vWF antigen II, immunoglobulins, plasma protease inhibitors, and histidine-rich glycoprotein.

Finally, lysosomes release clearing factors such as cathepsins, proteases, and glycohydrolases. Lysosome-release requires a stronger type of stimulus, such as thrombin or high doses of collagen, whereas alpha- and dense-granules are readily released with weaker types of stimulation, such as platelet exposure to ADP (Gresele et al., 2002).

\section{ELECTROPHYSIOLOGICAL EFFECTS OF ACTIVATED PLATELET PRODUCTS}

Many of the substances released by platelets can alter the electrophysiological properties of the heart in various animal species (Flores et al., 1999).

\section{Amines}

Serotonin or 5-hydroxytryptamine $(5-\mathrm{HT})$ is not synthesized in platelets but is actively taken up from the plasma and accumulated in dense granules where it is likely complexed with ATP and potentially with calcium (De Clerck et al., 1984). The serotonin released by exocytosis is relatively stable and functions as a weak platelet agonist on $5 \mathrm{HT}_{2}$ receptors (De Clerck et al., 1984), although it is probably less important in this respect than ADP. The positive feedback effect of serotonin may be of secondary importance to its vasoconstrictive action, which reduces flow at the site of injury and thereby limits blood loss (De Clerck, 1986). Dense granular concentration of serotonin was calculated to be
$65 \mathrm{mM}$ (Holmsen and Weiss, 1979), whereas (platelet-rich) plasma serotonin concentration was $842 \pm 58 \mathrm{nmol} / \mathrm{L}$ in healthy individuals (Vikenes et al., 1999). Serotonin can be used to assess the platelet release reaction: it locally increased 18 - to 27 -fold from normal levels in tissue surrounding a coronary thrombus in a dog model (Ashton et al., 1986).

Human atrial and ventricular cardiomyocytes express $5-\mathrm{HT}_{4}$ receptors (Kaumann et al., 1990; Bach et al., 2001), and exposure to serotonin results in tachycardia, increased atrial contractility, and atrial arrhythmias (Kaumann and Levy, 2006). 5-HT causes an up to sixfold increase in L-type $\mathrm{Ca}^{2+}$ channel current through $5-\mathrm{HT}_{4}$ receptors, in atrial myocytes from patients in sinus rhythm (Ouadid et al., 1992; Pau et al., 2003). Likewise, serotonin has positive inotropic and lusitropic effects on ventricular cardiomyocytes (Brattelid et al., 2004). Arrhythmic effects have also been observed and are probably mainly related to $\mathrm{Ca}^{2+}$-overload mediated by an increase in L-type $\mathrm{Ca}^{2+}$ current (Kaumann, 1994). Antidepressants from the selective serotonin reuptake inhibitor class (SSRI) have QT prolonging effects in patients with SSRI intoxications. The major clinical interaction with cardiovascular disease is likely its platelet inhibiting effect, which may reduce incidence of MI (Sauer et al., 2003).

Like, serotonin, histamine is another amine present in dense granules. Resting human platelets contain $25 \mathrm{ng}$ histamine $/ 10^{8}$ platelets, which can increase toward $47 \mathrm{ng} / 10^{8}$ platelets upon platelet activation (Jancinová and Nosál, 1998). The major arrhythmic effects of histamine consist of $\mathrm{H} 1$-receptor mediated slowing of AV nodal conduction and $\mathrm{H} 2$-receptor mediated increase in sinus rate and ventricular automaticity (Wolff and Levi, 1986). Histamine also has a positive inotropic effect on ventricular cardiomyocytes (Ginsburg et al., 1980).

In addition to serotonin, histamine can also cause vasoconstriction as further discussed below.

\section{Nucleotide derivatives}

Extracellular purines (adenosines, ADP, and ATP) and pyrimidines [uridine diphosphate (UDP) and uridine triphosphate (UTP)] can initiate a wide range of intracellular signaling cascades through purinergic receptors (Ralevic and Burnstock, 1998). Platelet-dense granules contain a high concentration of ATP (436 mM) and ADP (653 mM; Holmsen and Weiss, 1979), which can accelerate platelet activation binding to ADP receptors upon release. Normal extracellular ATP concentration is about $2 \mu \mathrm{M}$ (Born and Kratzer, 1984) and may increase to $100 \mu \mathrm{M}$ under pathological conditions (Coade and Pearson, 1989). Under normal conditions, ATP is rapidly converted to adenosine (Flores et al., 1999).

In rat and mouse ventricular cardiomyocytes, exposure to ATP induces a cytosolic $\mathrm{Ca}^{2+}$ rise and has positive inotropic effects (Danziger et al., 1988; Pucéat et al., 1991; Mei and Liang, 2001). By activation of purinergic receptors, ATP induces sustained increases in diastolic $\mathrm{Ca}^{2+}$ and triggers multiple $\mathrm{Ca}^{2+}$ waves, leading to DADs in current clamped mouse hearts (Gurung et al., 2009).

\section{Ions}

The dense granular concentration of calcium was calculated to be 2.2 M (Holmsen and Weiss, 1979). The total amount of calcium in human platelets is $10.1 \mu \mathrm{mol} / 10^{11}$ platelets (Meyers et al., 1982). In 
Table 1 | Platelet granules and their contents.

\begin{tabular}{|c|c|c|}
\hline Dense granules & Alpha-granules & Lysosomal granules \\
\hline Serotonin & Albumin & Cathepsin D \\
\hline Histamine & Fibrinogen & Cathepsin E \\
\hline ATP & Fibronectin & Carboxypeptidase A \\
\hline ADP & Vitronectin & Carboxypeptidase B \\
\hline Calcium & Osteonectin & Proline carboxypeptidase \\
\hline Magnesium & Calcitonin & $\beta$ - $N$-acetyl-D-hexosaminidase \\
\hline \multirow[t]{35}{*}{ Pyrophosphate } & Von Willebrand Factor & $\beta$-D-glucuronidase \\
\hline & Von Willebrand antigen II & $\beta$-D-galactosidase \\
\hline & Thrombospondin & $\alpha$-D-mannosidase \\
\hline & Platelet factor 4 & $\alpha$-L-arabinofuranosidase \\
\hline & $\lg G, \lg A, \lg M$ & $\alpha$-D-galactosidase \\
\hline & C1 inhibitor & $\alpha-$-Lfucosidase \\
\hline & Plasminogen & $\beta$-D-fucosidase \\
\hline & $\begin{array}{l}\text { Plasminogen activator } \\
\text { inhibitor-1 }\end{array}$ & $\beta$-D-glucosidase \\
\hline & $\begin{array}{l}\text { Platelet-derived } \\
\text { collagenase inhibitor }\end{array}$ & $\alpha$-D-glucosidase \\
\hline & $\begin{array}{l}\text { High molecular weight } \\
\text { kininogen }\end{array}$ & Acid phosphatase \\
\hline & Angiotensinogen & Arylsulfatase \\
\hline & Protein S & \\
\hline & $\alpha_{2}$-Antitrypsin & \\
\hline & $\alpha_{2}$-Macroglobulin & \\
\hline & $\alpha_{2}$-Antiplasmin & \\
\hline & Multimerin & \\
\hline & Platelet basic protein & \\
\hline & $\beta$-Thromboglobulin & \\
\hline & Histidine-rich & \\
\hline & glycoprotein & \\
\hline & Connective tissue- & \\
\hline & activating protein III & \\
\hline & $\begin{array}{l}\text { Neutrophil-activating } \\
\text { protein II }\end{array}$ & \\
\hline & Platelet-derived & \\
\hline & growth factor & \\
\hline & Coagulation factor $V$ & \\
\hline & Coagulation factor VIII & \\
\hline & Substance P & \\
\hline & Vasoactive intestinal & \\
\hline & peptide & \\
\hline & $>300$ other proteins & \\
\hline & (Maguire et al., 2002; & \\
\hline & Maguire and Fitzgerald, & \\
\hline & 2003; Coppinger & \\
\hline & et al., 2004) & \\
\hline
\end{tabular}

Table adapted from McNicol and Israels (1999).

humans, arrhythmias related to high calcium and magnesium levels are rare (Diercks et al., 2004). The normal plasma concentration of $\mathrm{Ca}^{2+}$ ranges from 1.03 to $1.23 \mathrm{mmol} / \mathrm{L}$ (Larsson and Ohman, 1978). The $\mathrm{Ca}^{2+}$ concentration in dense granules is very high, but the amount of released $\mathrm{Ca}^{2+}$ relative to the plasma concentration is small. The platelets in $1 \mathrm{~mL}$ blood (about $250 \times 10^{9}$ ) contain about $25.3 \mathrm{nmol}$ of $\mathrm{Ca}^{2+}$, and upon release would increase the local $\mathrm{Ca}^{2+}$ concentration by about $2 \%$ (presuming a volume of dispersion of $1 \mathrm{~mL}$ ). This raw estimate does not take into account the high concentration of platelets in an actual thrombus and the washout of $\mathrm{Ca}^{2+}$ during the non-occlusive phase of thrombus formation.

The platelet content of $\mathrm{Mg}^{2+}$, the second most abundant ion, is much smaller that the $\mathrm{Ca}^{2+}$ content. Platelets contain about $0.4 \mu \mathrm{mol} / 10^{11}$ platelets of releasable magnesium (Meyers et al., 1982). Normal plasma concentrations of $\mathrm{Mg}^{2+}$ range between 0.6 and $0.7 \mathrm{mmol} / \mathrm{L}$. A large influence of platelet $\mathrm{Mg}^{2+}$ release during platelet aggregation is therefore less likely than it is for $\mathrm{Ca}^{2+}$.

\section{Thromboxane, arachidonic acid, and other alpha-granule contents}

During platelet activation, arachidonic acid is liberated by phospholipase-A2 from membrane phospholipids and is converted enzymatically to epoxyeicosatrienoic acids (EETs) via the cyclooxygenase and lipoxygenase pathways. EETs have several effects on cardiac tissues (Flores and Sheridan, 1990; Xiao, 2007). EETs inhibit cardiac $\mathrm{Na}^{+}$channels (Lee et al., 1999), significantly increase intracellular $\mathrm{Ca}^{2+}$ concentrations in isolated guinea pig cardiomyocytes (Moffat et al., 1993), and significantly modulate the activities of cardiac $\mathrm{Ca}^{2+}$ channels (Chen et al., 1999) and KATP channels (Lee et al., 1999). Furthermore EETs can uncouple neonatal rat cardiac myocytes by reducing gap-junction conductance (Massey et al., 1992).

Thromboxane is an arachidonic-acid derivative that is prothrombotic and released by platelets. Thromboxane is produced by cyclooxygenase from prostanoids, a process that is inhibited by aspirin. Thromboxane is chemically unstable in blood, but its stable analog, U41669, has been shown to increase automaticity and to increase both resting and peak intracellular $\mathrm{Ca}^{2+}$ concentrations and induce irregular $\mathrm{Ca}^{2+}$ transients in isolated neonatal rat ventricular myocytes (Hoffmann et al., 1993). This is supported by the fact that these effects can be reversed in rabbit cardiomyocytes by blockade of U41669 (Wacker et al., 2009).

Chien et al. examined the effects of platelet products of rabbit platelets on cytosolic calcium in chick embryonic heart cells. They identified the arrhythmic platelet product(s) as small trypsin-sensitive peptide(s) (Chien et al., 1990). Examples of such small peptides, found in alpha-granules, are substance $\mathrm{P}$, calcitonin, vasoactive intestinal peptide, and angiotensinogen. Of the latter three no direct cardiac effects have been described. Substance P has only recently been found to be present in relatively high concentrations in platelets (Jones et al., 2008). It is primarily known as a neurotransmitter of pain sensation, but also has cardiovascular effects which are primarily mediated through vasodilatation. However, direct cardiac effects have been described: induction of bradycardia and hypotension in denervated and anesthetized rats (Tompkins et al., 1999).

Besides these, alpha-granules contain a long list of substances (Table 1) which can be subdivided in proteoglycans, adhesive glycoproteins, hemostatic factors, cellular mitogens, protease inhibitors, and miscellaneous other molecules (Rendu and Brohard-Bohn, 2001). Platelet proteomic approaches have tried to assess all proteins present in platelets (Maguire and Fitzgerald, 2003; McRedmond et al., 2004). Proteomics of the products of activated platelets have 
revealed more than 300 proteins (Maguire et al., 2002; Coppinger et al., 2004) which are mostly secreted in alpha-granules. Most of these proteins are present in only small quantities. Large electrophysiologic effects would therefore likely be mediated through membrane channels on cardiomyocytes.

\section{Lysosomal products}

Platelet lysosomes contain "clearing factors" that breakdown the platelet clot: acid proteases and glycohydrolases. These lysosomal products have no known effect on cardiomyocytes. Breakdown products of platelet clots could potentially be arrhythmogenic, however a review on the incidence of early ventricular arrhythmias after thrombolytic therapy did not show evidence for increased early arrhythmias (Solomon et al., 1993).

\section{VASOCONSTRICTION}

Several dense granule products have been shown to have effects on coronary smooth muscle cells that mediate coronary constriction. ATP, UTP, and ADP can mediate prostacyclin and nitric-oxide release by interaction with the $\mathrm{P} 2 \mathrm{Y}$ receptors on endothelial cells (da Silva et al., 2009). Serotonin injected in coronary arteries of angina patients leads to intense coronary constriction (McFadden et al., 1991), probably mediated by vascular $5-\mathrm{HT}_{1 \mathrm{~B}}$ and $5-\mathrm{HT}_{2 \mathrm{~A}}$ receptors (Kaumann and Levy, 2006). Like serotonin, histamine is another strong vasoconstrictor. In patients with variant angina, histamine could induce coronary spasm in $47 \%$ of subjects in one study (Kaski et al., 1986). Thrombus-released vasoconstrictive substances could reduce coronary perfusion and thereby increase local ischemia and reduce blood supply by collateral vessels. Ischemia due to coronary spasm in the absence of severe atherosclerosis has been described as a cause of VF (Seniuk et al., 2002; Al-Sayegh et al., 2007; Hung et al., 2007; Hendriks et al., 2008; Sanna et al., 2009; Sansone et al., 2009).

\section{ENDOTHELIAL PERMEABILITY}

Increased endothelial permeability during myocardial infarction can facilitate leakage of platelet products from the coronary lumen to epicardial myocytes. Increased endothelial permeability could be induced by platelet products or by ischemia. Indeed in a rat model of cerebral ischemia, thrombin injection induced vascular disruption, and increased permeability (Chen et al., 2010). In another study, platelet activating factor (PAF) greatly increased coronary permeability by the inhibition of endogeneous NO synthesis (Filep et al., 1993). And, in a hamster model, PAF increased permeability of the microvasculature of the cheek pouch (Ramírez et al., 1995). Also, serotonin has been shown to increase vascular permeability in different animal models (Clerck et al., 1984).

Ischemia also induces coronary permeability as animal studies have shown. In a dog model, 15 min of coronary occlusion could increase protein leakage by $50 \%$ (Dauber et al., 1990). And, in a rat model, $20 \mathrm{~min}$ of severe ischemia increased transcapillary albumin flux by 100\% (Sunnergren and Rovetto, 1980, 1987). Both the direct ischemic effects and the effects induced by platelet products promote interaction of platelet products and the myocardial tissue surrounding the ischemic coronary.

\section{EFFECTS ON MYOCARDIAL CONTRACTILITY}

Both increases and decreases in myocardial contractility have been found in experiments with substances released by platelets. ATP has strong positive inotropic effects in rats. ATP stimulates a large increase in cytosolic $\mathrm{Ca}^{2+}$ transients (Danziger et al., 1988; Christie et al., 1992). ATP also increases the L-type $\mathrm{Ca}^{2+}$ current in rats, and both mechanisms can induce positive inotropic effects (Scamps and Vassort, 1990). Further upstream in rats and mice, activation of $P_{2}$ purinergic receptors exerts a positive inotropic effect on cardiomyocytes and intact hearts by increasing intracellular ATP levels (Mei and Liang, 2001). Thrombin promotes $\mathrm{Ca}^{2+}$ entry and release in cardiomyocytes (Chien et al., 1990). Serotonin has positive inotropic effects on the human atria through the $\mathrm{HT}_{4}$ receptor, but such a receptor is absent in human ventricular cardiomyocytes (Kaumann, 1994).

Negative inotropic effects have been described for tumor necrosis factor- $\alpha$ in rats (Edmunds et al., 1999; Tabrizchi, 2001). It is likely that these effects leverage toward a positive inotropic effect of platelet products, as was confirmed by a study that added aggregating platelets to a bath of cat papillary muscles resulting in positive inotropic effects (Shah et al., 1989). Also, injection of low-dosed PAF into coronary arteries resulted in strong positive inotropic effects in isolated rabbit hearts (Alloatti et al., 1990).

\section{INTERACTION OF EFFECTS OF PLATELET PRODUCTS AND ISCHEMIC EFFECTS}

Arrhythmias are very common during cardiac ischemia and are the result of a multifactorial process. Ischemia is the most important factor in arrhythmia occurrence. This is evidenced by the fact that the absence of active platelets does not completely eliminate occurrence of VF in coronary ligation studies described above (Johnson et al., 1981; Chien et al., 1990; Coronel et al., 1997). Platelet products strongly increase the risk of arrhythmias in the setting of myocardial ischemia. It is tempting to speculate which platelet products have the strongest role in arrhythmia occurrence. From the clinical setting we know that ischemic VF often occurs within the first minutes after onset of chest pain, and it's risk declines during the first hours. An arrhythmic mediator should therefore be released readily upon platelet activation and exert it's effect within seconds as also has been observed in the animal models.

Amines from dense granules are readily released in high concentrations and alter cardiomyocyte electrophysiology directly, which makes them likely candidates. On top of that serotonininduced vasoconstriction could undermine collateral perfusion of the ischemic area. As a result of the findings of Chien et al., small trypsin-sensitive peptide(s) released by platelets, such as substance $\mathrm{P}$, deserves further investigation. Increased endothelial permeability induced by ischemia promotes interaction between these substances and cardiomyocytes. An unstable thrombus with fragment embolization could lead to increased local heterogeneity.

\section{PLATELET ANTAGONISTS AND ARRHYTHMIA PREVENTION}

Antiplatelet therapy is known to improve survival after myocardial infarction (Lau et al., 1992), while patients with increased platelet aggregation have a worse prognosis postmyocardial infarction 
(Trip et al., 1990). However, it is difficult to separate the beneficial effect of preventing thrombotic coronary occlusion from the potential anti-arrhythmic effects achieved during ischemia by preventing formation of platelet activation products. However, some evidence does exist for such an effect. Platelet antagonists effectively induced ventricular arrhythmias in models of ischemia by coronary ligation in rats (Ahn et al., 1999) and dogs (Moschos et al., 1978; Wainwright et al., 1989). In a dog model of regional ischemia, the threshold of epinephrine-induced VF was reduced after aspirin pre-treatment (Shehadeh et al., 2000). In a rat model of coronary occlusion, sarpogrelate, a 5-hydroxytryptamine $2 \mathrm{~A}$ receptor antagonist, but not cilostazol, a phosphodiesterase-III inhibitor, was able to prevent ventricular arrhythmias during ischemia (Barta et al., 2008). Sarpogrelate has multiple fields of action, including inhibition of serotonin-induced coronary spasm. However, administering aspirin after platelet activation had occurred did not block anti-arrhythmic effects of platelet products in isolated rabbit hearts (Alloatti et al., 1990).

\section{SUMMARY AND CONCLUSION}

The role of platelets in the occurrence of SCD extends beyond coronary flow impairment by clot formation. During clot formation platelets release a plethora of substances, many with potent arrhythmic properties. Platelet products are released from three types of platelet granules: dense core granules, alpha-granules, and platelet lysosomes. The physiologic properties of dense

\section{REFERENCES}

Ahn, Y. K., Cho, J. G., Park, W. S., Kim, N. H., Kim, J. W., Kim, S. H., Cho, J. H., Park, J. H., Jeong, M. H., Park, J. C., and Kang, J. C. (1999). The effects of antiplatelet agents in the prevention of ventricular tachyarrhythmias during acute myocardial ischemia in rats. Jpn. Heart J. 40, 79-86.

Akar, J. G., and Akar, F. G. (2007). Regulation of ion channels and arrhythmias in the ischemic heart. J. Electrocardiol. 40, S37-S41.

Al-Sayegh, A., Shukkur, A. M., and Akbar, M. (2007). Automatic implantable cardioverter defibrillator for the treatment of ventricular fibrillation following coronary artery spasm: a case report. Angiology 58, 122-125.

Alloatti,G.,Montrucchio, G., and Camussi, G. (1990). Prostacyclin inhibits the platelet-dependent effects of plateletactivating factor in the rabbit isolated heart. J. Cardiovasc. Pharmacol. 15, 745-751.

Ashton, J.H., Benedict, C. R., Fitzgerald, C., Raheja, S., Taylor, A., Campbell, W. B., Buja, L. M., and Willerson, J. T. (1986). Serotonin as a mediator of cyclic flow variations in stenosed canine coronary arteries. Circulation 73, 572-578.

Bach, T., Syversveen, T., Kvingedal, A. M., Krobert, K.A., Brattelid, T., Kaumann, A. J., and Levy, F. O. (2001). 5HT4(a) and 5-HT4(b) receptors have nearly identical pharmacology and are both expressed in human atrium and ventricle. Naunyn-Schmiedeberg's Arch. Pharmacol. 363, 146-160.

Barta, J., Sanganalmath, S. K., Kumamoto, H., Takeda, N., Edes, I., and Dhalla, N. S. (2008). Antiplatelet agents sarpogrelate and cilostazol affect experimentally-induced ventricular arrhythmias and mortality. Cardiovasc. Toxicol. 8, 127-135.

Born, G. V., and Kratzer, M. A. (1984). Source and concentration of extracellular adenosine triphosphate during haemostasis in rats, rabbits and man. J. Physiol. 354, 419-429.

Brattelid, T., Qvigstad, E., Lynham, J. A., Molenaar, P., Aass, H., Geiran, O., Skomedal, T., Osnes, J.-B., Levy, F. O., and Kaumann, A. J. (2004). Functional serotonin 5-HT4 receptors in porcine and human ventricular myocardium with increased 5-HT4 mRNA in heart failure. Naunyn-Schmiedeberg's Arch. Pharmacol. 370, 157-166.

Carmeliet, E. (1999). Cardiac ionic currents and acute ischemia: from channels to arrhythmias. Physiol. Rev. 79, 917-1017.

Chen, B., Cheng, Q., Yang, K., and Lyden, P. D. (2010). Thrombin mediates severe neurovascular injury during ischemia. Stroke 41, 2348-2352.

Chen, J., Capdevila, J.H., Zeldin, D. C., and Rosenberg, R. L. (1999). Inhibition of cardiac L-type calcium channels by epoxyeicosatrienoic acids. Mol. Pharmacol. 55, 288-295.

granule products are of special interest as a potential source of arrhythmic substances. They are released readily upon activation and contain high concentrations of serotonin, histamine, purines (adenosines, ADP, and ATP), pyrimidines (UDP and UTP), and ions such as $\mathrm{Ca}^{2+}$ and $\mathrm{Mg}^{2+}$. The mode of action of these substances ranges from induction of coronary constriction (serotonin), $\mathrm{Ca}^{2+}$ overloading (serotonin), and the induction of DADs (ATP).

Alpha-granules contain thromboxanes and other arachidonic-acid products with many potential arrhythmic effects mediated by interference with cardiac $\mathrm{K}^{+}$and $\mathrm{Ca}^{2+}$ channels. Alpha-granules also contain a large number of proteins in much lower concentrations that could potentially serve as a ligand to receptors on cardiomyocytes. Substance $\mathrm{P}$ is of particular interest. Lysosomal products are clearing factors that result in breakdown products of clots; but clinical studies do not suggest an important role of lysosomal products in arrhythmias, as evidenced by the absence of arrhythmia-induction during thrombolysis.

Antiplatelet therapy is known to improve survival after myocardial infarction. Although an important part of this effect results from the prevention of coronary clot formation, there is evidence to suggest that antiplatelet therapy also has anti-arrhythmic effects during ischemia by preventing the release of platelet activation products.

Chien, W. W., Mohabir, R., Newman, D. Leung, L. L., and Clusin, W. T. (1990) Effect of platelet release products on cytosolic calcium in cardiac myocytes. Biochem. Biophys. Res. Commun. 170, 1121-1127.

Christie, A., Sharma, V. K., and Sheu, S S. (1992). Mechanism of extracellular ATP-induced increase of cytosolic $\mathrm{Ca} 2+$ concentration in isolated rat ventricular myocytes. J. Physiol. 445, 369-388.

Chugh, S. S., Reinier, K., Teodorescu, C., Evanado, A., Kehr, E., Al Samara, M., Mariani, R., Gunson, K., and Jui, J. (2008). Epidemiology of sudden cardiac death: clinical and research implications. Prog. Cardiovasc. Dis. 51, 213-228.

Clerck, F., Nueten, J. M., and Reneman, R. S. (1984). Platelet-vessel wall interactions: implication of 5-hydroxytryptamine. A review. Agents Actions 15, 612-626.

Coade, S. B., and Pearson, J. D. (1989). Metabolism of adenine nucleotides in human blood. Circ. Res. 65, 531-537.

Coppinger, J. A., Cagney, G., Toomey, S., Kislinger, T., Belton, O., McRedmond, J. P., Cahill, D. J., Emili, A., Fitzgerald, D. J., and Maguire, P. B. (2004). Characterization of the proteins released from activated platelets leads to localization of novel platelet proteins in human atherosclerotic lesions. Blood 103, 2096-2104.
Coronel, R., Fiolet, J. W., WilmsSchopman, F. J., Schaapherder, A. F., Johnson, T. A., Gettes, L. S., and Janse, M. J. (1988). Distribution of extracellular potassium and its relation to electrophysiologic changes during acute myocardial ischemia in the isolated perfused porcine heart. Circulation 77, 1125-1138.

Coronel, R., Wilms-Schopman, F. J., and Janse, M. J. (1997). Profibrillatory effects of intracoronary thrombus in acute regional ischemia of the in situ porcine heart. Circulation 96, 3985-3991.

Coronel,R.,Wilms-Schopman,F.J.,Opthof, T., van Capelle, F. J., and Janse, M. J. (1991). Injury current and gradients of diastolic stimulation threshold, TQ potential, and extracellular potassium concentration during acute regional ischemia in the isolated perfused pig heart. Circ. Res. 68, 1241-1249.

da Silva, C. G., Specht, A., Wegiel, B., Ferran, C., and Kaczmarek, E. (2009). Mechanism of purinergic activation of endothelial nitric oxide synthase in endothelial cells. Circulation 119, 871-879.

Danziger, R. S., Raffaeli, S., MorenoSanchez, R., Sakai, M., Capogrossi, M. C., Spurgeon, H. A., Hansford, R. G., and Lakatta, E. G. (1988). Extracellular ATP has a potent effect to enhance cytosolic calcium and contractility in single ventricular myocytes. Cell Calcium 9, 193-199. 
Dauber, I. M., VanBenthuysen, K. M., McMurtry, I. F., Wheeler, G. S., Lesnefsky, E. J., Horwitz, L. D., and Weil, J.V. (1990). Functional coronary microvascular injury evident as increased permeability due to brief ischemia and reperfusion. Circ. Res. 66, 986-998.

Davies, M. J., and Thomas, A. (1984). Thrombosis and acute coronaryartery lesions in sudden cardiac ischemic death. N. Engl. J. Med. 310, 1137-1140.

De Clerck, F. (1986). Blood platelets in human essential hypertension. Agents Actions 18, 563-580.

De Clerck, F., Xhonneux, B., Leysen, J., and Janssen, A. P. (1984). Evidence for functional 5-HT2 receptor sites on human blood platelets. Biochem. Pharmacol. 33, 2807-2811.

Dekker, L. R., Fiolet, J. W., VanBavel, E., Coronel, R., Opthof, T., Spaan, J. A., and Janse, M. J. (1996). Intracellular $\mathrm{Ca} 2+$, intercellular electrical coupling, and mechanical activity in ischemic rabbit papillary muscle. Effects of preconditioning and metabolic blockade. Circ. Res. 79, 237-246.

Diercks, D. B., Shumaik, G. M., Harrigan, R. A., Brady, W. J., and Chan, T. C. (2004). Electrocardiographic manifestations: electrolyte abnormalities. J. Emerg. Med. 27, 153-160.

Edmunds, N. J., Lal, H., and Woodward, B. (1999). Effects of tumour necrosis factor-alpha on left ventricular function in the rat isolated perfused heart: possible mechanisms for a decline in cardiac function. Br. J. Pharmacol. 126, 189-196.

Filep, J. G., Földes-Filep, E., and Sirois, P. (1993). Nitric oxide modulates vascular permeability in the rat coronary circulation. Br. J. Pharmacol. 108, 323-326.

Flores, N. A., Botchway, A. N., Stavrou, B. M., and Sheridan, D. J. (1999). Cardiac electrophysiological effects of plateletderived substances. Exp. Physiol. 84, 253-274.

Flores, N. A., and Sheridan, D. J. (1990). Electrophysiological and arrhythmogenic effects of platelet activating factor during normal perfusion, myocardial ischaemia and reperfusion in the guinea-pig. Br. J. Pharmacol. 101, 734-738.

Frink, R. J., Rooney, P. A., Trowbridge, J. O., and Rose, J.P. (1988). Coronary thrombosis and platelet/fibrin microemboli in death associated with acute myocardial infarction. Br. Heart J. 59, 196-200.

Ginsburg, R., Bristow, M. R., Stinson, E. B., and Harrison, D. C. (1980). Histamine receptors in the human heart. Life Sci. 26, 2245-2249.

Greer, J. P. (2008). Wintrobe's Clinical Hematology. Philadelphia: Lippincott Williams and Wilkins.
Gresele, P., Page, C. P., and Vermylen, J. (2002).Platelets in Thromboticand Nonthrombotic Disorders. Cambridge, UK: Cambridge University Press.

Gurung, I. S., Kalin, A., Grace, A. A., and Huang, C. L.-H. (2009). Activation of purinergic receptors by ATP induces ventricular tachycardia by membrane depolarization and modifications of Ca2+homeostasis. J. Mol. Cell. Cardiol. 47, 622-633.

Hendriks, M. L., Allaart, C. P., Bronzwaer, J. G. F., Res, J. J. C., and de Cock, C. C. (2008). Recurrent ventricular fibrillation caused by coronary artery spasm leading to implantable cardioverter defibrillator implantation. Europace 10, 1456-1457.

Hoffman, B. F., Feinmark, S. J., and Guo, S.D. (1997). Electrophysiologic effects of interactions between activated canine neutrophils and cardiac myocytes. J. Cardiovasc. Electrophysiol. 8, 679-687.

Hoffman, B. F., Guo, S. D., and Feinmark, S. J. (1996). Arrhythmias caused by platelet activating factor.J. Cardiovasc. Electrophysiol. 7, 120-133.

Hoffmann, P., Heinroth-Hoffmann, I., and Toraason, M. (1993). Alterations by a thromboxane $\mathrm{A} 2$ analog (U46619) of calcium dynamics in isolated rat cardiomyocytes. J. Pharmacol. Exp. Ther. 264, 336-344.

Holmsen, H., and Weiss, H. J. (1979). Secretable storage pools in platelets. Annu. Rev. Med. 30, 119-134.

Hung, M.-J., Cheng, C.-W., Yang, N.-I., Hung, M.-Y., and Cherng, W.-J. (2007). Coronary vasospasminduced acute coronary syndrome complicated by life-threatening cardiac arrhythmias in patients without hemodynamically significant coronary artery disease. Int. J. Cardiol. $117,37-44$.

Jancinová, V., and Nosál, R. (1998). Increased histamine content in Ca2+-ionophore A23187-activated human blood platelets. Platelets 9 , 203-206.

Johnson, G. J., Heckel, R., Leis, L. A., and Franciosa, J. (1981). Effect of inhibition of platelet function with carbenicillin or aspirin on experimental canine sudden death. J. Lab. Clin. Med. $98,660-672$.

Jones, S., Tucker, K. L., Sage, T., Kaiser, W. J., Barrett, N. E., Lowry, P. J., Zimmer, A., Hunt, S. P., Emerson, M., and Gibbins, J. M. (2008). Peripheral tachykinins and the neurokinin receptor NK1 are required for platelet thrombus formation. Blood 111, 605-612.

Kaski, J.C., Crea, F., Meran, D., Rodriguez, L., Araujo, L., Chierchia, S., Davies, G., and Maseri, A. (1986). Local coronary supersensitivity to diverse vasoconstrictive stimuli in patients with variant angina. Circulation 74 , 1255-1265.

Kaumann, A. J. (1994). Do human atrial 5-HT4 receptors mediate arrhythmias? Trends Pharmacol. Sci. 15, 451-455.

Kaumann, A. J., and Levy, F. O. (2006). 5 -hydroxytryptamine receptors in the human cardiovascular system. Pharmacol. Ther. 111, 674-706.

Kaumann, A. J., Sanders, L., Brown, A. M., Murray, K. J., and Brown, M. J. (1990). A 5-hydroxytryptamine receptor in human atrium. Br. J. Pharmacol. 100, 879-885.

Kléber,A. G., Riegger, C. B., and Janse, M. J. (1987). Electrical uncoupling and increase of extracellular resistance after induction of ischemia in isolated arterially perfused rabbit papillary muscle. Circ. Res. 61, 271-279.

Larsson, L., and Ohman, S. (1978). Serum ionized calcium and corrected total calcium in borderline hyperparathyroidism. Clin. Chem. 24, 1962-1965.

Lau, J., Antman, E. M., Jimenez-Silva J., Kupelnick, B., Mosteller, F., and Chalmers, T. C. (1992). Cumulative meta-analysis of therapeutic trials for myocardial infarction. N. Engl. J. Med. $327,248-254$.

Lee, H. C., Lu, T., Weintraub, N. L., VanRollins, M., Spector, A. A., and Shibata, E. F. (1999). Effects of epoxyeicosatrienoic acids on the cardiac sodium channels in isolated rat ventricular myocytes. J. Physiol. 519(Pt 1), 153-168.

Lown, B., and Wolf,M. (1971).Approaches to sudden death from coronary heart disease. Circulation 44, 130-142.

Maguire, P. B., and Fitzgerald, D. J. (2003). Platelet proteomics. J. Thromb. Haemost. 1, 1593-1601.

Maguire, P. B., Wynne, K. J., Harney, D. F., O'Donoghue, N. M., Stephens, G., and Fitzgerald, D. J. (2002). Identification of the phosphotyrosine proteome from thrombin activated platelets. Proteomics 2, 642-648.

Massey, K. D., Minnich, B. N., and Burt, J. M. (1992). Arachidonic acid and lipoxygenase metabolites uncouple neonatal rat cardiac myocyte pairs. Am. J. Physiol. 263, C494-C501.

McFadden, E. P., Clarke, J. G., Davies, G. J., Kaski, J. C., Haider, A. W., and Maseri, A. (1991). Effect of intracoronary serotonin on coronary vessels in patients with stable angina and patients with variant angina. N. Engl. J. Med. 324, 648-654.

McNicol, A., and Israels, S. J. (1999). Platelet dense granules: structure, function and implications for haemostasis. Thromb. Res. 95, 1-18.

McRedmond, J. P., Park, S. D., Reilly, D. F., Coppinger, J. A., Maguire, P. B., Shields, D. C., and Fitzgerald, D. J. (2004). Integration of proteomics and genomics in platelets: a profile of platelet proteins and platelet-specific genes. Mol. Cell. Proteomics 3, 133-144.

Mei, Q., and Liang, B. T. (2001). P2 purinergic receptor activation enhances cardiac contractility in isolated rat and mouse hearts. Am. J. Physiol. Heart Circ. Physiol. 281, H334-H341.

Meyers, K.M.,Holmsen, H., and Seachord, C. L. (1982). Comparative study of platelet dense granule constituents. Am. J. Physiol. 243, R454-R461.

Moffat, M. P., Ward, C. A., Bend, J. R., Mock, T., Farhangkhoee, P., and Karmazyn, M. (1993). Effects of epoxyeicosatrienoic acids on isolated hearts and ventricular myocytes. Am. J. Physiol. 264, H1154-H1160.

Moschos, C. B., Haider, B., De La Cruz, C., Lyons, M. M., and Regan, T. J. (1978). Antiarrhythmic effects of aspirin during nonthrombotic coronary occlusion. Circulation 57, 681-684.

Ouadid, H., Seguin, J., Dumuis, A., Bockaert, J., and Nargeot, J. (1992). Serotonin increases calcium current in human atrial myocytes via the newly described 5-hydroxytryptamine4 receptors. Mol. Pharmacol. 41, 346-351.

Pau, D., Workman, A. J., Kane, K. A., and Rankin, A. C. (2003). Electrophysiological effects of 5-hydroxytryptamine on isolated human atrial myocytes, and the influence of chronic beta-adrenoceptor blockade. Br. J. Pharmacol. 140 1434-1441.

Pucéat, M., Clément, O., Scamps, F., and Vassort, G. (1991). Extracellular ATPinduced acidification leads to cytosolic calcium transient rise in single rat cardiac myocytes. Biochem. J. 274(Pt 1), 55-62.

Ralevic, V., and Burnstock, G. (1998). Receptors for purines and pyrimidines. Pharmacol. Rev. 50 413-492.

Ramírez, M. M., Quardt, S. M., Kim, D., Oshiro, H., Minnicozzi, M., and Durán, W. N. (1995). Platelet activating factor modulates microvascular permeability through nitric oxide synthesis. Microvasc. Res. 50, 223-234.

Rendu, F., and Brohard-Bohn, B. (2001) The platelet release reaction: granules' constituents, secretion and functions. Platelets 12, 261-273.

Saito, T., Sato, T., Miki, T., Seino, S., and Nakaya, H. (2005). Role of ATP-sensitive $\mathrm{K}+$ channels in electrophysiological alterations during myocardial ischemia: a study using Kir6.2-null mice. Am. J. Physiol. Heart Circ. Physiol. 288, H352-H357.

Sanna, T., Lanza, G. A., Niccoli, G., La Torre, G., Cosentino, N., and Crea, F. (2009). Coronary artery vasospasm 
causing ventricular fibrillation - an external loop recording. Resuscitation 80, 393-394.

Sansone, F., Trichiolo, S., Ceresa, F., Attisani, M., Berardo, A., and Rinaldi, M. (2009). Recurrent ventricular fibrillation due to coronary artery spasm immediately after ascending aorta replacement. J. Cardiovasc. Med. (Hagerstown) 10, 810-812.

Sauer, W. H., Berlin, J. A., and Kimmel, S. E. (2003). Effect of antidepressants and their relative affinity for the serotonin transporter on the risk of myocardial infarction. Circulation 108, 32-36.

Scamps, F., and Vassort, G. (1990). Mechanism of extracellular ATPinduced depolarization in rat isolated ventricular cardiomyocytes. Pflugers Arch. 417, 309-316.

Seniuk, W., Mularek-Kubzdela, T., Grygier, M., Grajek, S., and Cieśliński, A. (2002). Cardiac arrest related to coronary spasm in patients with variant angina: a three-case study. J. Intern. Med. 252, 368-376.

Shah, A. M., Meulemans, A. L., and Brutsaert, D. L. (1989). Myocardial inotropic responses to aggregating platelets and modulation by the endocardium. Circulation 79, 1315-1323.

Shehadeh, A. A., Arena, J., Moschos, C. B., and Regan, T. J. (2000). Nonplatelet effects of aspirin during acute coronary occlusion: electrophysiologic and cation alterations in ischemic myocardium. J. Cardiovasc. Pharmacol. Ther. 5, 113-120.

Solomon, S. D., Ridker, P. M., and Antman, E. M. (1993). Ventricular arrhythmias in trials of thrombolytic therapy for acute myocardial infarction. A meta-analysis. Circulation 88, 2575-2581.

Sunnergren, K. P., and Rovetto, M. J. (1980). Microvascular permeability characteristics of the isolated perfused ischemic rat heart. J. Mol. Cell. Cardiol. 12, 1011-1031.

Sunnergren, K. P., and Rovetto, M. J. (1987). Myocyte and endothelial injury with ischemia reperfusion in isolated rat hearts. Am. J. Physiol. Heart Circ. Physiol. 252, H1211-H1217.

Tabrizchi, R. (2001). The influence of tumour necrosis factor-alpha on the cardiovascular system of anaesthetized rats. Naunyn-Schmiedeberg's Arch. Pharmacol. 363, 307-321.

Ter Keurs, H. E., and Boyden, P.A. (2007). Calcium and arrhythmogenesis. Physiol. Rev. 87, 457-506.

Tompkins, J. D., Hoover, D. B., and Hancock, J. C. (1999). Substance P evokes bradycardia by stimulation of postganglionic cholinergic neurons. Peptides 20, 623-628.

Trip, M. D, Cats, V. M., van Capelle, F. J., and Vreeken, J. (1990). Platelet hyperreactivity and prognosis in survivors of myocardial infarction. N. Engl. J. Med. 322, 1549-1554.

Verkerk,A.O., Veldkamp, M.W., Bouman, L. N., and van Ginneken, A. C. (2000) Calcium-activated $\mathrm{Cl}(-)$ current contributes to delayed after depolarizations in single Purkinje and ventricular myocytes. Circulation 101, 2639-2644.

Vikenes, K., Farstad, M., and Nordrehaug, J. E. (1999). Serotonin is associated with coronary artery disease and cardiac events. Circulation 100, 483-489.
Wacker, M. J., Kosloski, L. M., Gilbert, W. J. R., Touchberry, C. D., Moore, D. S. Kelly, J. K., Brotto, M., and Orr, J. A. (2009). Inhibition of thromboxane A2-induced arrhythmias and intracellular calcium changes in cardiac myocytes by blockade of the inositol trisphosphate pathway. J. Pharmacol. Exp. Ther. 331, 917-924.

Wainwright, C. L., Parratt, J. R., and Bigaud, M. (1989). The effects of PAF antagonists on arrhythmias and platelets during acute myocardial ischaemia and reperfusion. Eur. Heart J. 10, 235-243.

Wilde, A. A., Escande, D., Schumacher, C. A., Thuringer, D., Mestre, M., Fiolet, J. W., and Janse, M. J. (1990). Potassium accumulation in the globally ischemic mammalian heart. A role for the ATPsensitive potassium channel. Circ. Res. 67, 835-843.

Wolff,A.A., and Levi, R. (1986). Histamine and cardiac arrhythmias. Circ. Res. 58, $1-16$.

Xiao, Y.-F. (2007). Cyclic AMP-dependent modulation of cardiac L-type Ca2+ and transient outward $\mathrm{K}+$ channel activities by epoxyeicosatrienoic acids. Prostaglandins Other Lipid Mediat. 82, 11-18.

Zipes, D. P., Camm, A. J., Borggrefe, M., Buxton, A. E., Chaitman, B., Fromer M., Gregoratos, G., Klein, G., Moss, A. J., Myerburg, R. J., Priori, S. G. Quinones, M. A., Roden, D. M., Silka, M. J., Tracy, C., Smith, S. C., Jr., Jacobs, A. K., Adams, C. D., Antman, E. M., Anderson, J. L., Hunt, S. A., Halperin, J. L., Nishimura, R., Ornato, J. P., Page, R. L., Riegel, B., Priori, S. G., Blanc, J. J., Budaj, A., Camm, A. J., Dean, V.,
Deckers, J. W., Despres, C., Dickstein, K., Lekakis, J., McGregor, K., Metra, M., Morais, J., Osterspey, A., Tamargo, J. L., and Zamorano, J.L.(2006).ACC/AHA/ ESC 2006 guidelines for management of patients with ventricular arrhythmias and the prevention of sudden cardiac death: a report of the American College of Cardiology/American Heart Association Task Force and the European Society of Cardiology Committee for Practice Guidelines (Writing Committee to Develop Guidelines for Management of Patients With Ventricular Arrhythmias and the Prevention of Sudden Cardiac Death). J. Am. Coll. Cardiol. 48, e247-e346.

Conflict of Interest Statement: The authors declare that the research was conducted in the absence of any commercial or financial relationships that could be construed as a potential conflict of interest.

Received: 17 November 2010; accepted: 14 December 2010; published online: 30 December 2010.

Citation: de Jong JSSG and Dekker LRC (2010) Platelets and cardiac arrhythmia. Front. Physio. 1:166. doi: 10.3389/ fphys.2010.00166

This article was submitted to Frontiers in Cardiac Electrophysiology, a specialty of Frontiers in Physiology.

Copyright (c) 2010 de Jong and Dekker. This is an open-access article subject to an exclusive license agreement between the authors and the Frontiers Research Foundation, which permits unrestricted use, distribution, and reproduction in any medium, provided the original authors and source are credited. 